\title{
Hypoglycemic Activity of Leaf Extracts from Tiliacora triandra in Normal and Streptozotocin-Induced Diabetic Rats
}

\author{
Teeraporn Katisart ${ }^{1 *}$, Surapong Rattana ${ }^{2}$
}

\section{Teeraporn Katisart ${ }^{*}$, Surapong Rattana ${ }^{2}$}

${ }^{1}$ Department of Biology, Faculty of Science, Mahasarakham University, THAILAND

${ }^{2}$ Pharmaceutical chemistry and Natural Products Research Unit, Faculty of Pharmacy, Mahasarakham University, THAILAND

\section{Correspondence}

Teeraporn Katisart, Department of Biology, Faculty of Science,

Mahasarakham University, THAILAND.

Tel.: +66 43 754245; Fax: +66 43 754245?

E-mail: tkatisart@gmail.com (T. Katisart)

History

- Submission Date: 21-03-2017

- Review completed: 13-05-2017;

- Accepted Date: 02-06-2017

DOI : 10.5530/pj.2017.5.99

Article Available online

http://www.phcogj.com/v9/i5

\section{Copyright}

(c) 2017 Phcog.Net. This is an openaccess article distributed under the terms of the Creative Commons Attribution 4.0 International license.

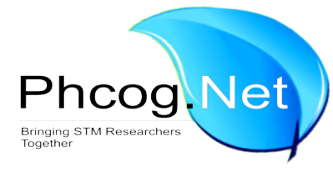

\begin{abstract}
Background: Tiliacora triandra is a common plant found in southeast Asian countries. It is traditionally used as anti-pyrogenic agent. Objective: The present study was aimed to investigate the hypoglycemic activities leaf extracts from Tiliacora triandra (TTE) in normal and streptozotocin-induced diabetic rats. Methods: TTE was prepared and daily and orally administered at dose of $300 \mathrm{mg} / \mathrm{kg}$ b.w. to the rats for 8 weeks. The body weight and blood glucose level were measured weekly. At the end of the experiments, blood samples were collected from cardiac puncture and analyzed for serum insulin levels. The pancreatic tissues were stained by hematoxylin-eosin for histo-pathological investigations. Results: Normal and diabetic rats treated with TTE and glibenclamide tended to have an increased body weight. TTE significantly decreased the blood glucose level by $25.01 \pm 19.77 \%$ in week 3 in diabetic rats and similar to that of glibenclamide group $(27.01 \pm 11.89 \%)$. However, the extracts slightly decreased the blood glucose level in normal rats by $9.48 \pm 2.14 \%$ in week 2 . TTE significantly increased serum insulin level by $21.63 \pm 1.39 \mathrm{IU} / \mathrm{mL}$ in diabetic rats compared to the controls $(10.63 \pm$ $0.37 \mathrm{IU} / \mathrm{mL}$ ) but not in normal rats. In additions, TTE activated the regeneration of pancreatic Islets of Langerhans in diabetic rats which in turn stimulated insulin secretion. Conclusion: TTE exhibits the hypoglycemic potential by stimulating insulin secretion from the pancreas.
\end{abstract}

Key words: Tiliacora triandra, Hypoglycemic effect, Streptozotocin-induced diabetic rats.

\section{INTRODUCTION}

Diabetes mellitus (DM) is a metabolic disease characterized by hyperglycemia. It is caused by insulin secretion deficiency or disorder of insulin function. The long term diabetes leads to the complications in various body systems such as diabetic retinopathy, nephropathy and neuropathy. ${ }^{1}$ It is estimated that in the year 2025, there will be 300 million patients suffered from diabetes. This amount is rising in the developing countries including Thailand. ${ }^{2}$ The government has taken into account to spend budget for production and import of chemically synthetic drugs such as insulin, glipiside, glibenclamide, metformin and acarbose. The interesting alternative is to use traditional medicine for treatment of diabetes.

Tiliacora triandra is a medicinal plant belonging to the family Menispermaceae. It is a common indigenous plants found in south-east Asia including Thailand. ${ }^{3}$ The leaves of Tiliacora triandra has been used as an ingredient in young bamboo soup because it could reduce the toxicity of bamboo shoot. It has been used in Thai traditional medicine for the treatment of fever. ${ }^{4}$ Pharmacological study of leaf extracts revealed that it showed high anti-oxidant capacity in accordance with high flavonoid and phenolic compound contents. ${ }^{5,6}$ These findings corresponded to the study by Singthong et al. who found that water leaf extract of Tiliacora triandra provided phenolic compound and showed high antioxidant activities. ${ }^{7}$ Kaewpiboon et al. found that three fatty acid from leaf extract of Tiliacora triandra enhanced P-glycoprotein function in multidrug-resistant A549RT-eto cell line. ${ }^{8}$ Arial part extract of Tiliacora triandra is effective in treating brain dysfunction induced by alcohol and possess anti-tumor and anti-cancer activity. ${ }^{9-11}$ Alkaloids from Tiliacora triandra also exhibit antimycobacterial activity against multidrug-resistant isolates of Mycobacterium tuberculosis. ${ }^{12}$ However, the root extract of this plant contained two pure alkaloid compounds called tiliacorinine and tiliacorine with anti-malarial activity. ${ }^{13,14}$ In additions, the root extracts also exhibit anti-pyretic activity. ${ }^{15,16}$ For toxicity study, it was found that the water extract from this plant does not cause acute or subchronic toxicities in either male or female rats. ${ }^{17}$ In additions, leaf extract from Tiliacora triandra showed alpha-glucosidase inhibitory activity suggesting the decrease of glucose absorption in small intestine. This finding suggested the potential of this plant in prevention of hyperglycemia. ${ }^{18}$ However, there is no report on anti-diabetic activity of this plant extracts in animal models. Therefore, the objectives of this study are to study the hypoglycemic effect of ethanolic leaf extracts from Tiliacora triandra and to study the 
possible mechanism of action of these extracts in lowering blood glucose level in animal model of diabetes.

\section{MATERIALS AND METHODS}

\section{Preparation of plant extracts}

Tiliacora triandra was cultivated in Mahasarakham province, Northeastern part of Thailand. The specimen was deposited at department of Biology, faculty of Science, Mahasarakham University, Thailand (code: MSU.SC-BI-TK1). The leaves were collected and dried in the hot air oven at $50{ }^{\circ} \mathrm{C}$ for $48 \mathrm{~h}$. The leaves were ground as powder $(1,000 \mathrm{~g})$ and then macerated with $95 \%$ ethanol $(4,000 \mathrm{ml})$ for 7 days. The solvent was removed using a rotary evaporator. The extracts were then dried using a freeze dryer to get a powder. The $95 \%$ ethanolic leaf extracts (TTE) were kept at $-20{ }^{\circ} \mathrm{C}$ until use.

\section{Animals}

Male albino wistar rats were purchased from National Laboratory Animal Centre, Mahidol University, Thailand. The rats with body weight of 180-200 g were used. All rats were kept in separate cages. One control and one diabetic rat were kept in the same cage. Feed and water were provided daily to the rats for up to 8 weeks. All groups were kept in a temperature-controlled room $\left(22 \pm 2{ }^{\circ} \mathrm{C}\right)$, artificially lit from 6.00 to 18.00 hours daily. The initial weights and blood glucose levels of the rats were recorded weekly. The experimental protocol was approved by Mahasarakham University ethics committee, Mahasarakham, Thailand (License No. 0015/2015).

\section{Induction of diabetes in rats}

The rats were fasted for 8-12 h. The initial blood glucose level of rats from the tail vein was then measured using an Accu-Check active testing kit. Streptozotocin (STZ) was freshly dissolved in $20 \mathrm{mM}$ citrate buffer (pH 4.5) STZ was injected once and intraperitoneally at dose of $65 \mathrm{mg} / \mathrm{kg}$ body weight to the rats. Then $20 \mathrm{mM}$ citrate buffer ( $\mathrm{pH} 4.5)$ at an equal volume to the diabetic group was injected to the control rats. To avoid the initial hypoglycemia, $2 \%$ sucrose was added to drinking water for the streptozotocin-induced diabetic rats for 48 hours. Their blood glucose levels were measured immediately after one week of injection. The blood glucose level in control rats should be approximately $80 \mathrm{mg} / \mathrm{dL}$. For diabetic groups, the blood glucose level of $126 \mathrm{mg} / \mathrm{dL}$. or more is confirmed as diabetic. ${ }^{19}$

\section{Experimental designs}

The rats were divided into five experimental groups with six animals in each: group 1 was normal control rats treated orally with $0.5 \%$ tween 80; group 2 was normal rats treated with leaf extracts $(300 \mathrm{mg} / \mathrm{kg}$ b.w.); group 3 was diabetic control rats treated orally with $0.5 \%$ tween 80 ; group 4 was diabetic rats treated orally with glibenclamide $(0.25 \mathrm{mg} / \mathrm{kg}$ b.w. $)$ and Group 5 was diabetic rats treated with leaf extracts $(300 \mathrm{mg} / \mathrm{kg}$ b.w.
TTE and glibenclamide were suspended in $0.5 \%$ tween 80 and administered orally using orogastric tube daily for 8 weeks.

\section{Effect of TTE on body weight and fasting plasma glucose}

The normal and STZ-induced diabetic rats were fasted for 8-12 hours. Then blood samples were collected from the tail vein of the rats by using Accu-check Advantage II (Roche, Germany). FPG were measured weekly in each experimental groups.

\section{Effect of TTE on serum insulin}

Eight weeks after experiments, all the rats were fasted for 8-12 hours. They were sacrificed by cervical dislocation technique. Then, blood samples were drawn from the rat's heart. The blood samples were centrifuged at $3500 \mathrm{rpm}$ for $20 \mathrm{~min}$ to get serum. The serum samples were analyzed for insulin content by using immune radio assay kit (MP Bio chemicalsOrangeburg, USA).

\section{Histological studies}

The procedure of histological studies of pancreas was adapted according to the study by Zhang et al. (2010). ${ }^{20}$ After blood collection, all rats were sacrificed. The pancreatic tissues were removed. The tissues were then fixed in $10 \%$ buffered formalin after washing with normal saline. The tissues were processed for embedding in paraffin wax by routine protocols and $5-\mu \mathrm{m}$-thick sections were then cut by microtome. The tissues were stained with haematoxylin-eosin using a routine protocol and examined using photomicroscope.

\section{Statistical analysis}

All data were expressed as mean \pm standard error of mean (SEM). Statistical analysis was carried out using F-test (One-way ANOVA) followed by Scheffe's test. The criterion for statistical significance was at a $p$-value less than 0.05 .

\section{RESULTS}

\section{Effect of extracts on body weight}

The body weight of rats (as shown in Table 1) were measured weekly along 8 weeks of the experiments. The results showed that normal and diabetic rats treated with $300 \mathrm{mg} / \mathrm{kg}$ b.w. extracts had an increased body weight week by week in comparison with the normal controls. However, the diabetic control rats had the decreased body weight compared to the normal controls.

\section{Effect of extracts on fasting plasma glucose}

The fasting plasma glucose (FPG) of rats (as shown in Table 2) were also measured weekly along 8 weeks of the experiments. The results showed that normal and diabetic rats treated with $300 \mathrm{mg} / \mathrm{kg}$ b.w. extracts had the decreased fasting plasma glucose week by week in comparison with the normal controls. However, the diabetic control rats had an increased fasting plasma glucose compared to the normal controls. In this study,

Table 1: The effect of ethanolic extract of Tiliacora triandra on body weight in normal and streptozotocin-induced diabetic rats

\begin{tabular}{|c|c|c|c|c|c|c|c|c|c|}
\hline \multirow[t]{2}{*}{ Treatment } & \multicolumn{9}{|c|}{$\%$ increasing of BW } \\
\hline & Initial BW & Week 1 & Week 2 & Week 3 & Week 4 & Week 5 & Week 6 & Week 7 & Week 8 \\
\hline Cont. & $302.00 \pm 3.65$ & $5.50 \pm 0.71^{\mathrm{a}}$ & $19.13 \pm 0.95^{\mathrm{b}}$ & $28.03 \pm 1.59^{c}$ & $35.81 \pm 1.51^{c}$ & $44.45 \pm 1.59^{c}$ & $48.97 \pm 1.49^{c}$ & $52.67 \pm 1.78^{\mathrm{c}}$ & $57.56 \pm 1.55^{\mathrm{c}}$ \\
\hline Cont.+TTE & $303.00 \pm 8.65$ & $3.31 \pm 0.58^{\mathrm{a}}$ & $8.10 \pm 1.35^{\mathrm{a}}$ & $17.35 \pm 1.74^{\mathrm{b}}$ & $26.51 \pm 2.39^{b}$ & $30.75 \pm 3.11^{\mathrm{b}}$ & $40.74 \pm 2.83^{\mathrm{b}}$ & $44.13 \pm 2.93^{\mathrm{b}}$ & $48.63 \pm 3.10^{\mathrm{b}}$ \\
\hline DM & $212.00 \pm 11.74$ & $3.86 \pm 0.25^{\mathrm{a}}$ & $12.78 \pm 3.63^{a}$ & $13.66 \pm 3.15^{\mathrm{a}}$ & $15.24 \pm 3.21^{\mathrm{a}}$ & $16.93 \pm 3.34^{\mathrm{a}}$ & $0.00 \pm 0.00^{\mathrm{a}}$ & $17.13 \pm 2.74^{\mathrm{a}}$ & $17.34 \pm 2.93^{a}$ \\
\hline $\mathrm{DM}+\mathrm{GB}$ & $247.00 \pm 27.66$ & $3.06 \pm 0.48^{\mathrm{a}}$ & $13.84 \pm 2.10^{\mathrm{a}}$ & $16.88 \pm 1.60^{\mathrm{a}}$ & $21.39 \pm 3.62^{\mathrm{a}}$ & $24.42 \pm 4.02^{\mathrm{a}}$ & $27.64 \pm 5.50^{\mathrm{a}}$ & $30.35 \pm 5.87^{a}$ & $35.52 \pm 5.22^{b}$ \\
\hline $\mathrm{DM}+\mathrm{TTE}$ & $207.00 \pm 83.28$ & $4.78 \pm 1.80^{\mathrm{a}}$ & $12.57 \pm 1.80^{a}$ & $16.14 \pm 2.40^{\mathrm{a}}$ & $0.00 \pm 0.00^{\mathrm{a}}$ & $0.00 \pm 0.00^{\mathrm{a}}$ & $21.81 \pm 5.00^{a}$ & $25.81 \pm 4.40^{\mathrm{a}}$ & $31.55 \pm 6.40^{\mathrm{ab}}$ \\
\hline
\end{tabular}


Katisart and Rattana: Hypoglycemic activity of leaf extracts from Tiliacora triandra in normal and streptozotocin-induced diabetic rats

Table 2: The effect of ethanolic extract of Tiliacora triandra on fasting blood glucose in normal and streptozotocin-induced diabetic rats

\begin{tabular}{cccccccccc}
\hline Treatment & \multicolumn{7}{c}{ \% decreasing of FBG } \\
& $\begin{array}{c}\text { Initial FBG } \\
(\mathrm{mg} / \mathrm{dL})\end{array}$ & Week 1 & Week 2 & Week 3 & Week 4 & Week 5 & Week 6 & Week 7 & Week 8 \\
\hline Cont. & $84.00 \pm 1.53$ & $0.00 \pm 0.00^{\mathrm{a}}$ & $0.00 \pm 0.00^{\mathrm{a}}$ & $0.00 \pm 0.00^{\mathrm{a}}$ & $0.00 \pm 0.00^{\mathrm{a}}$ & $0.00 \pm 0.00^{\mathrm{a}}$ & $0.00 \pm 0.00^{\mathrm{a}}$ & $0.00 \pm 0.00^{\mathrm{a}}$ & $0.00 \pm 0.00^{\mathrm{a}}$ \\
Cont.+TTE & $94.00 \pm 2.76$ & $3.71 \pm 1.64^{\mathrm{b}}$ & $9.48 \pm 2.14^{\mathrm{b}}$ & $0.00 \pm 0.00^{\mathrm{a}}$ & $0.19 \pm 2.46^{\mathrm{ab}}$ & $4.49 \pm 3.59^{\mathrm{b}}$ & $2.22 \pm 2.37^{\mathrm{a}}$ & $0.00 \pm 0.00^{\mathrm{a}}$ & $0.53 \pm 2.82^{\mathrm{a}}$ \\
DM & $372.67 \pm 77.31$ & $11.98 \pm 4.78^{\mathrm{a}}$ & $20.88 \pm 4.18^{\mathrm{a}}$ & $11.05 \pm 6.29^{\mathrm{a}}$ & $0.00 \pm 0.00^{\mathrm{a}}$ & $0.00 \pm 0.00^{\mathrm{a}}$ & $0.00 \pm 0.00^{\mathrm{a}}$ & $0.00 \pm 0.00^{\mathrm{a}}$ & $0.00 \pm 0.00^{\mathrm{a}}$ \\
DM+GB & $399.50 \pm 74.85$ & $22.79 \pm 5.66^{\mathrm{a}}$ & $41.13 \pm 8.93^{\mathrm{a}}$ & $27.01 \pm 11.89^{\mathrm{a}}$ & $25.33 \pm 11.34^{\mathrm{ab}}$ & $23.37 \pm 11.39^{\mathrm{ab}}$ & $24.59 \pm 11.06^{\mathrm{ab}}$ & $25.15 \pm 11.11^{\mathrm{ab}}$ & $26.21 \pm 11.64^{\mathrm{ab}}$ \\
DM+TTE & $482.00 \pm 55.67$ & $22.77 \pm 4.76^{\mathrm{a}}$ & $2.10 \pm 19.86^{\mathrm{a}}$ & $25.01 \pm 19.77^{\mathrm{a}}$ & $13.84 \pm 21.41^{\mathrm{a}}$ & $3.34 \pm 20.42^{\mathrm{a}}$ & $4.49 \pm 21.30^{\mathrm{ab}}$ & $6.78 \pm 20.69^{\mathrm{ab}}$ & $15.73 \pm 18.96^{\mathrm{ab}}$ \\
\hline
\end{tabular}

Table 3: The effect of ethanolic extract of Tiliacora triandra on serum insulin levels in normal and streptozotocin-induced diabetic rats

\begin{tabular}{cc}
\hline Treatment & Insulin level (IU/mI) \\
\hline Cont. & $22.77 \pm 0.23^{\mathrm{b}}$ \\
Cont.+TTE & $23.02 \pm 0.64^{\mathrm{b}}$ \\
DM & $10.63 \pm 0.37^{\mathrm{a}}$ \\
DM+TTE & $21.63 \pm 1.39^{\mathrm{b}}$ \\
DM+GB & $21.22 \pm 1.87^{\mathrm{b}}$ \\
\hline
\end{tabular}

the rats were induced as diabetic by using streptozotocin (STZ). This induction caused the elevation of FPG up to 4 folds compared to those of the normal controls.

\section{Effect of extracts on serum insulin level}

As shown in Table 3, the serum insulin level of normal control rats was $22.77 \pm 0.23 \mathrm{IU} / \mathrm{mL}$. Interestingly, there was a significant reduction of insulin level in diabetic control rats, which was $10.63 \pm 0.37 \mathrm{IU} / \mathrm{mL}$. After 8 weeks of the treatment of leaf extracts, there was a significant increasing of insulin level in diabetic rats treated with leaf extracts of $21.63 \pm 1.39$ $\mathrm{IU} / \mathrm{mL}$ compared to the diabetic controls.

\section{Effect of extracts on histology of pancreas}

The results of Tiliacora triandra leaf extract treatments on pancreatic histology are shown in Figure 1. These results are in associated with the results from FPG and serum insulin level studies. It was found that the pancreas among the normal control rats had normal islet histological appearance. However, Islets of Langerhans in diabetic control rats are abnormal with smaller size and oval in shape than those of the normal controls. The islets of Langerhans of diabetic rats treated with leaf extract and glibenclamide tend to be larger than those of the diabetic controls. The diabetic rats treated with leaf extracts had the improved histological appearances of pancreas.

\section{DISCUSSION}

Hyperglycemia is a remarkable characteristic among diabetic patients. It usually alters the balance of free radicals and antioxidant levels. This may lead to the damage of pancreatic beta cells and induction of insulin resistance. STZ has the cytotoxic effect on pancreatic beta cells. It may be mediated by the inhibition of free radical scavenging enzymes which is related to the production of superoxide radical. This may be evident by a decrease of pancreatic islets size, degranulation of cells, vacuolation and invasion of connective tissues in those of the diabetic control group. ${ }^{20}$

The possible mechanism of blood glucose reduction produced by plant extracts could be explained by different mechanisms. Some plants may contain insulin-like substances. The others may increase $\beta$ cells in the

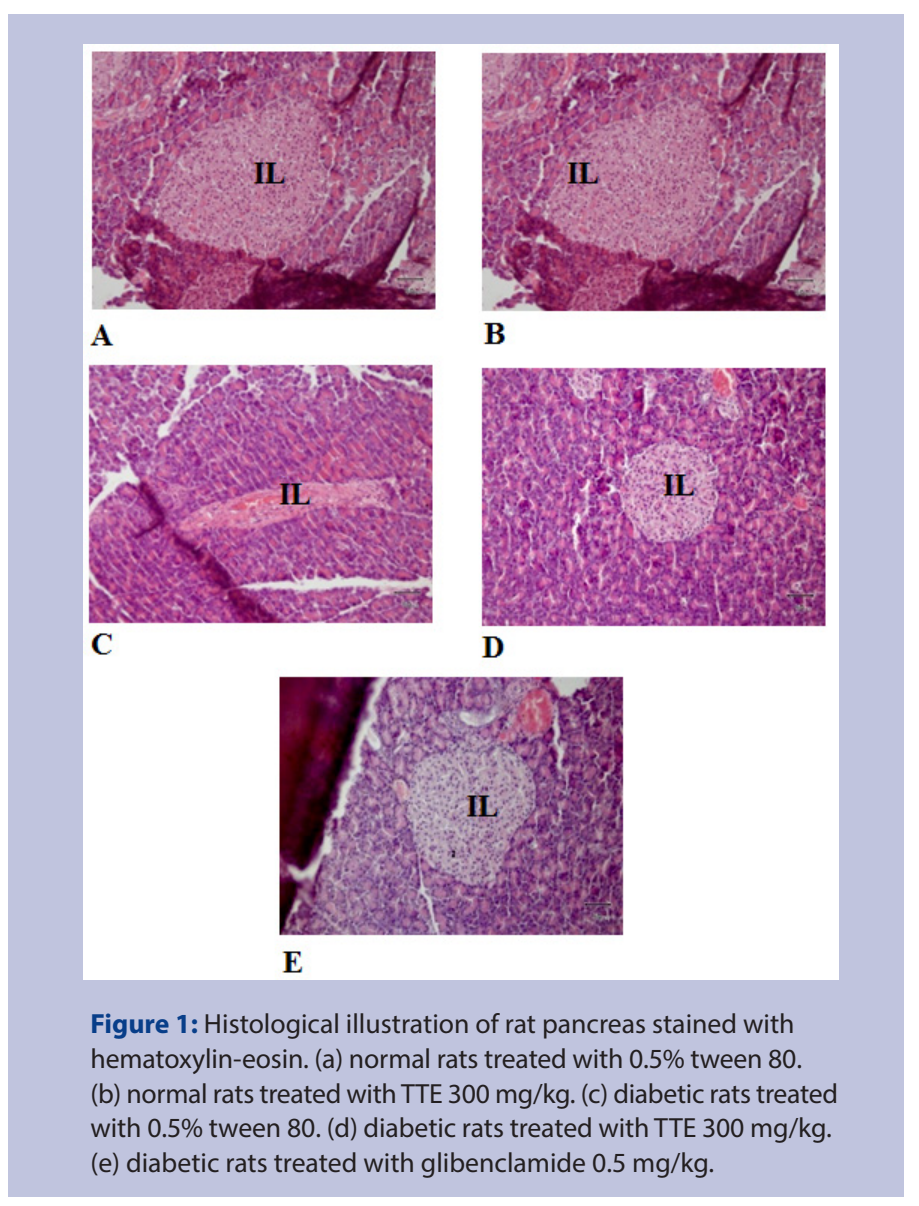

pancreas by activating the regeneration of these cells. The fiber of plants may also interfere with carbohydrate absorption and therefore affect blood glucose. ${ }^{21}$

A medicinal plant in the family Menispermaceae such as Tinospora crispa also exhibit hypoglycemic effect with insulin enhancing activity. ${ }^{22}$ However, hypoglycemic effect of Tinospora cordifolia may be through the glycogen storage in the liver or decreasing the glucose release from the liver. ${ }^{23}$ In the present study, it is clear that leaf extracts of Tiliacora triandra reduce blood glucose level in diabetic rats over eight weeks of the experiments. The extracts also increase body weight of all treatment groups. Treatment of the extracts causes the regeneration and histological improvement of pancreatic islets. This is confirmed by the elevation of serum insulin level in diabetic rats treated with the extracts. Therefore, it is assumed that the active ingredient of the extracts may act as insulin 
sensitizer which stimulates insulin secretion from the pancreas which in turn reduce or control the blood glucose levels.

\section{CONCLUSION}

The findings from this research can be concluded that leaf extracts from Tiliacora triandra exhibits the hypoglycemic potential by stimulating insulin secretion from the pancreas in STZ-induced diabetic rats without the significant hypoglycemic effect and body weight alterations in normal rats.

\section{ACKNOWLEDGEMENT}

The authors would like to acknowledge the National Research Council of Thailand (NRCT) for providing financial grant for completion of this research. We are also grateful to the Department of Biology, Faculty of Science, Mahasarakham University for supporting facilities.

\section{CONFLICT OF INTEREST}

Authors declare no conflict of interest.

\section{ABBREVIATIONS USED}

FBG: fasting blood glucose; BW: body weight; TTE: Tiliacora triandra leaf extract; STZ: Streptozotocin; GB: Glibenclamide; Cont.: control; DM: diabetes mellitus; IL: Islets of Langerhans.

\section{REFERENCES}

1. World Health Organization. Global status report on noncommunicable diseases 2014. World Health Organization 2014

2. King $H$, Aubert RE, Herman WH. Global burden of diabetes, 1995-2025: prevalence, numerical estimates, and projections. Diabetes Care. 1998;21(9):1414 31. https://doi.org/10.2337/diacare.21.9.1414; PMid:9727886

3. Forman LL, Menispermaceae. Flora of Thailand 1991;5(3):300-65

4. Maneenoon K, Khuniad C, Teanuan Y, Saedan N, Prom-in S, Rukleng N, et al. Ethnomedicinal plants used by traditional healers in Phatthalung Province, Peninsular Thailand. J Ethnobiol Ethnomedm. 2015;11(1):43. https://doi. org/10.1186/s13002-015-0031-5. https://doi.org/10.1186/s13002-015-0031-5; PMid:26025447 PMCid:PMC4469324.

5. Rattana S, Padungkit M, Cushnie, B. Phytochemical screening, flavonoid content and antioxidant activity of Tiliacora triandra leaf extracts. In Proceedings of the $2^{\text {nd }}$ Annual International Conference of Northeast Pharmacy Research 2010. (pp. 60-63).

6. Chaveerach A, Lertsatitthanakorn P, Tanee T, Puangjit N, Patarapadungkit N, Sudmoon R. Chemical constituents, antioxidant property, cytotoxicity and genotoxicity of Tiliacora triandra. IJPPR. 2016; 8:722-729.

7. Singthong J, Oonsivilai R, Oonmetta-Aree J, Ningsanond S. Bioactive compounds and encapsulation of Yanang (Tiliacora triandra) leaves. Afr J Tradit Complementary Altern Med. 2014;11(3):76-84. https://doi.org/ 10.4314/ajtcam. v11i3.2254.
8. Kaewpiboon C, Winayanuwattikun P, Yongvanich T, Phuwapraisirisan P, Assavalapsakul W. Effect of three fatty acids from the leaf extract of Tiliacora triandra on P-glycoprotein function in multidrug-resistant A549RT-eto cell line. Phcog Mag. 2014;10(3):S549. https://doi.org/10.4103/0973-1296.139779. PMid:25298673 PMCid:PMC4189271.

9. Phunchago N, Wattanathorn J, Chaisiwamongkol K. Tiliacora triandra, an antiintoxication plant, improves memory impairment, neurodegeneration, cholinergic function, and oxidative stress in hippocampus of ethanol dependence rats. Oxid Med Cell Longevity. 2015.9 pages. http://doi.org/10.1155/2015/918426.

10. Janeklang S, Nakaew A, Vaeteewoottacharn K, Seubwai W, Boonsiri, P, Kismali G, Wongkham S. In vitro and in vivo antitumor activity of tiliacorinine in human cholangiocarcinoma. Asian Pac J Cancer Prev. 2014;15(17):7473-8. http://doi. org/10.7314/APJCP.2014.15.17.7473.

11. Rattana S, Cushnie B, Taepongsorat L, Phadungkit M. Chemical constituents and In vitro anticancer activity of Tiliacora triandra leaves. Phcog J. 2016;8(1):1 3. http://doi.org/10.5530/pj.2016.1.1.

12. Sureram S, Senadeera SP, Hongmanee P, Mahidol C, Ruchirawat S, Kittakoop P Antimycobacterial activity of bisbenzylisoquinoline alkaloids from Tiliacora triandra against multidrug-resistant isolates of Mycobacterium tuberculosis. Bioorg Med Chem Lett. 2012;22(8):2902-5. http://doi.org/10.1016/j.bmcl.2012.02.053.

13. Saiin C, Markmee S. Isolation of anti-malaria active compound from Yanang (Tiliacora triandra Diels.). Kasetsart J Nat Sci. 2003;37:47-51.

14. Nutmakul T, Pattanapanyasat K, Soonthornchareonnon N, Shiomi K, Mori M, Prathanturarug S. Antiplasmodial stage specific activity of tiliacorinine and yanangcorinine, and their interaction effects with chloroquine. Planta Med Lett. 2016;81(S 01):P921. http://doi.org/10.1055/s-0036-1596922.

15. Jongchanapong A, Singharachai $C$, Palanuvej C, Ruangrungsi N, Towiwat P. Antipyretic and antinociceptive effects of Ben-cha-Lo-Ka-Wi-Chian remedy. J Health Res. 2010;24(1):15-22.

16. Singharachai $\mathrm{C}$, Palanuvej $\mathrm{C}$, Kiyohara $\mathrm{H}$, Yamada $\mathrm{H}$, Ruangrungsi N. Pharmacognostic specification of five root species in Thai traditional medicine remedy: BenCha-Lo-Ka-Wi-Chian. Phcog J. 2011;3(21):1-11. http://doi.org/10.5530/pj.2011.21.1.

17. Sireeratawong S, Lertprasertsuke N, Srisawat U, Thuppia, A, Ngamjariyawat $A$ Suwanlikhid N, et al. Acute and subchronic toxicity study of the water extract from Tiliacora triandra (Colebr.) Diels in rats. Songklanakarin J Sci Technol. 2008:30(5):611-9.

18. Neamsuvan O, Madeebing N, Mah L, Lateh W. A survey of medicinal plants for diabetes treating from Chana and Nathawee district, Songkhla province, Thailand. J Ethnopharmacol. 2015;174;82-90. http://doi.org/10.1016/j. jep.2015.07.050

19. Katisart T. Transient receptor potential function in bladder from control and streptozotocin treated rats (Doctoral dissertation, School of Life Sciences, Faculty of Health and Human Sciences, University of Hertfordshire) 2011.

20. Zhang L, Yang J, Chen XQ, Zan K, Wen XD, Chen H, et al. Antidiabetic and antioxidant effects of extracts from Potentilla discolor Bunge on diabetic rats induced by high fat diet and streptozotocin. J Ethnopharmacol. 2010;132(2):518-24. http://doi.org/10.1016/j.jep.2010.08.053.

21. Mohammadi J, Naik PR. The histopathologic effects of Morus alba leaf extract on the pancreas of diabetic rats. Turk J Biol. 2012;36(2):211-6.

22. Noor H, Ashcroft SJ. Antidiabetic effects of Tinospora crispa in rats. J Ethnopharmacol. 1989;27(1-2):149-61. https://doi.org/10.1016/0378-8741(89)90087-1. https://doi.org/10.1016/0378-8741(89)90087-1

23. Puranik N, Kammar KF, Devi S. Anti-diabetic activity of Tinospora cordifolia (Willd.) in streptozotocin diabetic rats; does it act like sulfonylureas?. Turk J Med Sci. 2010;40(2):265-70. https://doi.org/10.3906/sag-0802-40

\section{HIGHLIGHTS OF PAPER}

- Tiliacora triandra leaf extracts reduce fasting blood glucose level in diabetic rats.

- Tiliacora triandra leaf extracts increase body weight in normal and diabetic rats.

- Tiliacora triandra leaf extracts increase serum insulin level in diabetic rats.

- Tiliacora triandra leaf extracts improve the histological appearance of islets of Langerhans in diabetic rats.

- TTE $300 \mathrm{mg} / \mathrm{kg}$ b.w. $\Rightarrow$ increases body weight in all groups of rats.

- The extracts

- The extracts improves the histological appearance of islets of Langerhans in diabetic rats.

Body weight (BW) levels (FBG) Serum insulin leve Histology of pancreas 1 


\section{AUTHOR PROFILE}

Dr. Teeraporn Katisart: Obtained his Ph.D. in Pharmacology from the University of Hertfordshire, United Kingdom. He is currently a lecturer at the Department of Biology, Faculty of Science, Mahasarakham University, Thailand. His research is focused on the effects of medicinal plants and natural products on the animal models of diabetes and also their toxicities and other biological activities.

Cite this article : Katisart T, Rattana S. Hypoglycemic activity of leaf extracts from Tiliacora triandra in normal and streptozotocininduced diabetic rats. Pharmacog J. 2017;9(5):621-5. 